\title{
Invasive species and habitat degradation in Iberian streams: an analysis of their role in freshwater fish diversity loss
}

\author{
Virgilio Hermoso, ${ }^{1,2,7}$ Miguel Clavero, ${ }^{3,4}$ Francisco Blanco-Garrido, ${ }^{5}$ and José Prenda ${ }^{6}$ \\ ${ }^{1}$ The Ecology Centre, School of Biological Sciences, University of Queensland, St Lucia, Queensland 4072 Australia \\ ${ }^{2}$ Australian Rivers Institute, Griffith University, Nathan Campus, Kessels Road, Queensland 4411 Australia \\ ${ }^{3}$ Grup d'Ecologia del Paisatge, Area de Biodiversitat, Centre Tecnologic Forestal de Catalunya, \\ Carretera vella de Sant Llorenc de Morunys km 2, 25280 Solsona, Spain \\ ${ }^{4}$ Departament de Ciències Ambientals, Universitat de Girona, Campus de Montilivi, 17071 Girona, Spain \\ ${ }^{5}$ Mediodes, Consultoría Ambiental y Paisajismo S.L. Bulevar Louis Pasteur, 1 Blq. 2-1-1, 29010 Malaga, Spain \\ ${ }^{6}$ CIECEMA Parque Dunar s/n 21760 Matalascañas, Almonte, Huelva, Spain
}

\begin{abstract}
Mediterranean endemic freshwater fish are among the most threatened biota in the world. Distinguishing the role of different extinction drivers and their potential interactions is crucial for achieving conservation goals. While some authors argue that invasive species are a main driver of native species declines, others see their proliferation as a co-occurring process to biodiversity loss driven by habitat degradation. It is difficult to discern between the two potential causes given that few invaded ecosystems are free from habitat degradation, and that both factors may interact in different ways.

Here we analyze the relative importance of habitat degradation and invasive species in the decline of native fish assemblages in the Guadiana River basin (southwestern Iberian Peninsula) using an information theoretic approach to evaluate interaction pathways between invasive species and habitat degradation (structural equation modeling, SEM). We also tested the possible changes in the functional relationships between invasive and native species, measured as the per capita effect of invasive species, using ANCOVA.

We found that the abundance of invasive species was the best single predictor of natives' decline and had the highest Akaike weight among the set of predictor variables examined. Habitat degradation neither played an active role nor influenced the per capita effect of invasive species on natives. Our analyses indicated that downstream reaches and areas close to reservoirs had the most invaded fish assemblages, independently of their habitat degradation status. The proliferation of invasive species poses a strong threat to the persistence of native assemblages in highly fluctuating environments. Therefore, conservation efforts to reduce native freshwater fish diversity loss in Mediterranean rivers should focus on mitigating the effect of invasive species and preventing future invasions.
\end{abstract}

Key words: ANCOVA; driver; freshwater fish; functional vs. numerically mediated process; passenger; per capita effect; SEM.

\section{INTRODUCTION}

The diversity of life on Earth is rapidly declining under the current biodiversity crisis (Olson et al. 2002). Extinction rates are 100-1000 times higher than prehuman levels in many different taxonomic groups and across a wide range of environments (Pimm et al. 1995). This situation is especially worrying in freshwater environments worldwide (Dudgeon et al. 2006), and Mediterranean systems in particular. In a recent review of the conservation status of Mediterranean endemic freshwater fish, Smith and Darwall (2006) found that almost $70 \%$ of the species assessed (excluding data deficient species) were threatened with extinction or already extinct. There is a general agreement on the

Manuscript received 28 October 2009; revised 19 March 2010; accepted 19 March 2010. Corresponding Editor: K. B. Gido.

${ }^{7}$ E-mail: virgilio.hermoso@gmail.com urgent need for management actions focused on conserving biodiversity (Olson et al. 2002), but such actions require an understanding of the mechanisms driving biodiversity loss. The study of the relationships between extinction drivers and biodiversity loss thus transcend mere theoretical discussions, and it has clear implications for achieving conservation goals.

Many factors have been cited as extinction drivers. However, habitat degradation and invasive species are the most commonly cited causes of biodiversity loss (Ricciardi 2004, Clavero and García-Berthou 2005, Didham et al. 2007). Due to the frequent spatial (and temporal) co-occurrence of these factors (Fig. 1A), the ultimate mechanisms driving biodiversity loss often remain unclear (Gurevitch and Padilla 2004, Didham et al. 2007). Different views on this issue range from the perception that invasive species are mere passengers (i.e., a co-occurring though basically independent phenomenon) of the biodiversity loss process driven by 

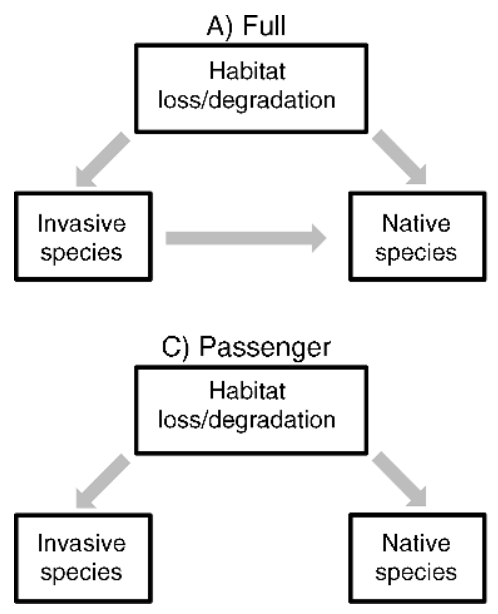
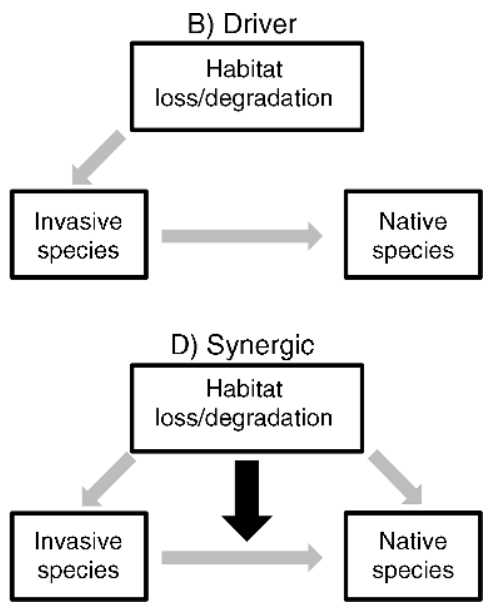

FIG. 1. Conceptual models explaining alternative pathways responsible for the decline of native assemblages, including the two most commonly cited causes of biodiversity loss: habitat degradation and invasive species. (A) A full model, where both factors are responsible for the decline of native assemblages. (B, C) Two alternative pathways, where invasive species act as drivers of native decline (only invasive species would have direct effects on natives) or passenger (habitat degradation would be the leading cause of the decline of native species). (D) An additional interactive pathway, where habitat degradation could be enhancing (i.e., numerically or functionally mediated processes according to Didham et al. [2007]) the per capita effect of invasive species.

habitat degradation (Fig. 1C), to the designation of invasive species as main drivers of native species' decline (Fig. 1B; Didham et al. 2005). However, effective conservation action demands accurate identification of the relative roles of habitat degradation and invasive species to biodiversity loss. For example, eradication plans would be completely inefficient, and conservation budgets wasted, if invasive species just proliferate in degraded environments but have no effect on the decline of native species (Myers et al. 2000, Zavaleta et al. 2001).

Recently, some efforts have been devoted to analyze the roles of habitat degradation and invasive species in the decline and extinction of native species for different taxonomic groups, with contradictory conclusions (e.g., Marchetti et al. 2004, MacDougall and Turkington, 2005, Light and Marchetti 2006). Light and Marchetti (2006) tested the role of invasive freshwater fish species and habitat degradation in the decline of native fish assemblages in Californian streams, while MacDougall and Turkington (2005) used experimental designs to check the same hypothesis on plant assemblages in an oak savannah in Canada. While in the first example, Light and Marchetti (2006) identified invasive species as the primary driver in the decline of native freshwater fish assemblages, MacDougall and Turkington (2005) argued that invasive plants were mainly passengers in the decline of native species, suggesting that native species' recruitment limitations in degraded systems would be a consistent explanation for invasive species dominance.

Research on the two major drivers of biodiversity lost (habitat degradation and invasive species) is often approached as independent, single-factor problems (Fazey et al. 2005). However, these factors can also act synergistically through different interaction path- ways (Didham et al. 2007). Habitat degradation may promote increases in the local abundance or regional distribution of invaders, with total invasive impact scaling in direct proportion to invader abundance (i.e., without changes in the per capita impact; Fig. 1A). Habitat degradation can also change the mode of action or functional response of invasive species, with total impact scaling disproportionately with invader abundance (i.e., with changes in the per capita interaction effects; Fig. 1D). For example, habitat degradation causing loss of refugia could expose native species to higher predation rates by invasive species, resulting in an increased per capita effect. It is important to differentiate between these two pathways because they have different consequences for conservation management strategies (Didham et al. 2007).

Mediterranean freshwater ecosystems harbor a highly endemic freshwater fish fauna (Reyjol et al. 2007) featuring a large proportion of threatened species (Smith and Darwall 2006). These systems have suffered a long history of habitat degradation, including modifications of flow regimes, urban and agricultural spills, dam construction, river channelization, and destruction of riverine vegetation (Allan and Flecker 1993, Cowx 2002, Collares-Pereira and Cowx 2004). They are also among the most heavily invaded ecosystems in the world (Leprieur et al. 2008).

To address these issues, we evaluated the role of invasive species, different sources of habitat perturbation, natural environmental gradients, and their potential interactions in the decline of native freshwater fish assemblages in a Mediterranean basin. We tested the hypotheses represented in Fig. 1 on a wide range of conditions: from pristine areas with no invasive species 
and low habitat degradation to highly perturbed areas or fish assemblages completely dominated by invasive species, as well as intermediate combinations of both factors (e.g., areas with good habitat condition but highly invaded). We first evaluated if invasive species were acting as "drivers" (Fig. 1B) or "passengers" (Fig. 1C) in the process of native fish biodiversity loss led by other factors, such as habitat degradation, at the reach scale. This work is a refinement of previous work carried out by Marchetti et al. (2004) and Light and Marchetti (2006) on freshwater fish assemblages at coarser spatial scales. We then evaluated the effect of habitat degradation in the relationship between invasive fish species and native assemblages, testing whether native species simply responded to the abundance of invasive species (Fig. $1 \mathrm{~A}-\mathrm{C}$ ) or if habitat degradation modified the functional relationships between natives and invasives (Fig. 1D). We also analyzed the effects of natural upstreamdownstream gradients, one of the most important natural factors structuring stream fish assemblages (Angermeier and Schlosser 1989, Matthews 1998, Magalhães et al. 2002), on the relationship between invasive and native species. Moreover we check the role of reservoirs, which act as centers for fish introductions facilitating nonnative establishment and subsequent expansion within basins (Clavero et al. 2004, Havel et al. 2005, Johnson et al. 2008) in the decline of native assemblages.

\section{Methods \\ Study area}

The Guadiana River basin is located in the southwestern Iberian Peninsula and drains a total area of $67039 \mathrm{~km}^{2}$ to the Atlantic Ocean. It features a typical Mediterranean climate, with high intra- and interannual variability in discharge, including severe and unpredictable floods between autumn and spring and persistent summer droughts (Gasith and Resh 1999). Mean air temperature ranges from $13.0^{\circ}$ to $18.1^{\circ} \mathrm{C}$, with strong intra-annual variation in extreme temperatures. Mean annual precipitation ranges from 350 to $1200 \mathrm{~mm}$ (with a mean of $450 \mathrm{~mm}$ ). Although it is not an overpopulated area (28 inhabitants $\left./ \mathrm{km}^{2}\right)$, this landscape has been strongly transformed during the last century by agricultural activities. Almost half of the basin (49.1\%) is currently under agricultural use. As a consequence, about $11000 \mathrm{GL}$ of water is retained in 88 large reservoirs $(>1 \mathrm{GL})$ and more than 200 small ones $(<1$ GL) for water supply. This has resulted in the modification of natural flow regimes and has seriously fragmented the basin. Water abstraction in wells is also a problem in some areas of the basin, where thousands of legal exploitations, and an uncertain number of illegal ones, have negative consequences for the main aquifers. Other common human perturbations include river channel modifications and complete destruction of the riparian forest (Hermoso et al. 2009b). In regards to biotic degradation, a total of 13 invasive species are also present in this basin (Hermoso et al. 2008), some of which are widely distributed (Table 1).

Guadiana's freshwater fish fauna, with 14 native species found in this study (Table 1), is especially relevant within the circum-Mediterranean context, where mean species richness is usually below this value (Smith and Darwall 2006). Moreover, almost two-thirds (64.3\%) of the native species in the basin are currently threatened based on IUCN criteria (Table 1).

\section{Fish and habitat data}

Fish assemblages were characterized in 170 localities (Fig. 2) in the Guadiana River basin, using electrofishing during spring (April-June) in 2002, 2005, and 2006. Sampling was conducted through a single-pass at each location without block-nets along a minimum of $100 \mathrm{~m}$ stretches whenever possible, covering all habitats available at this scale following the recommendations of the FAME Consortium (2004) for European rivers. This sampling method was selected to adequately characterize spatial trends in abundance and species richness (Bertrand et al. 2006, Sály et al. 2009). All fish were identified to species and returned to the water. Abundances were standardized as captures per unit of effort by the total length surveyed and time devoted (catch per unit effort, CPUE $=$ number of fish/[length] $\times$ time; where length is measured in meters and time is measured in hours).

Habitat was characterized by 33 environmental variables, covering three different spatial scales: site, reach (defined as a buffer area of $500 \mathrm{~m}$ around the sampling site) and basin (Appendix). In situ variables (except water quality measures) were characterized using a stratified approach from transects perpendicular to the river channel located every $20 \mathrm{~m}$ within the surveyed site. At each transect three different point measures were recorded and mean values from all transects were used in analyses. Basin scale data included a set of variables generated from GIS layers that characterized climatic parameters, land uses and spatial measures (e.g., distances to main stem Guadiana River, distance to headwaters and mouth. See the Appendix for more information on these variables). Climatic variables were extracted from the digital climatic map of the Iberian Peninsula (Ninyerola et al. 2005), based on long temporal series (15-50 yr). We assumed that these data represented an average year in the area. For land cover data, we used a digital map provided by the Guadiana Basin's management authority (Confederación Hidrográfica del Guadiana), representing land cover status in 2003. All environmental metrics fell within two categories: (1) variables that described the natural environmental variability in the basin (i.e., not subjected to direct human influences) and (2) descriptors of human perturbations (Appendix). These variables were selected as they have been highlighted as important factors explaining fish assemblage structure, such as stream size and position 
TABLE 1. List of freshwater fish species present in the Guadiana River basin, natural distribution area, threatened status according to IUCN (2008), and their prevalence within the 170 sampled sites.

\begin{tabular}{llcc}
\hline \hline \multicolumn{1}{c}{ Species } & \multicolumn{1}{c}{ Distribution } & Threat status & Prevalence (\%) \\
\hline Iberocypris alburnoides & Iberian Peninsula & VU & 45 \\
Cobitis paludica & Iberian Peninsula & VU & 44 \\
Squalius pyrenaicus & Iberian Peninsula & NT & 22 \\
Luciobarbus microcephaus & Guadiana River & VU & 21 \\
Iberochondrostoma lemmingii & Iberian Peninsula & VU & 18 \\
Luciobarbus comizo & Iberian Peninsula & VU & 16 \\
Pseudochondrostoma willkommii & Iberian Peninsula & VU & 12 \\
Salaria fluviatilis & circunmediterranean & LC & 9 \\
Luciobarbus sclateri & Iberian Peninsula & LC & 7 \\
Anaecypris hispanica & Guadiana River & EN & 5 \\
Gobio lozanoi & Iberian Peninsula & LC & 2 \\
Luciobarbus guiraonis & Iberian Peninsula & VU & 1 \\
Anguilla anguilla & North Atlantic & CR & 1 \\
Alosa alosa & Eastern Atlantic & LC & $<1$ \\
Lepomis gibbosus & nonnative & & 44 \\
Gambusia holbrooki & nonnative & & 38 \\
Micropterus salmoides & nonnative & & 16 \\
Cyprinus carpio & nonnative & 6 \\
Ameiurus melas & nonnative & & 5 \\
Alburnus alburnus & nonnative & & 3 \\
Esox lucius & nonnative & & 3 \\
Carassius auratus & nonnative & & 1 \\
Australhoeros facetum & nonnative & & \\
Rutilus rutilus & nonnative & & \\
Scardinius erythropthalmus & nonnative & & \\
Fundulus heteroclitus & nonnative & &
\end{tabular}

Notes: Key to abbreviations: CR, critically endangered; EN, endangered; VU, vulnerable; NT, near threatened; LC, least concern. Scardinius erythropthalmus and Fundulus heteroclitus are cited in the basin but were not found in the present study.

within the watershed, habitat quality and land use (Oakes et al. 2005). All variables were checked for normality and transformed when necessary prior to analysis (arcsine for land use variables, expressed as percentages and $\log [x+1]$ for the rest).

\section{Definition of response and predictor variables}

We used two variables to represent the status of native freshwater fish assemblages: (1) total native species richness and (2) a measure of biotic integrity. Biotic integrity was assessed through an index of community

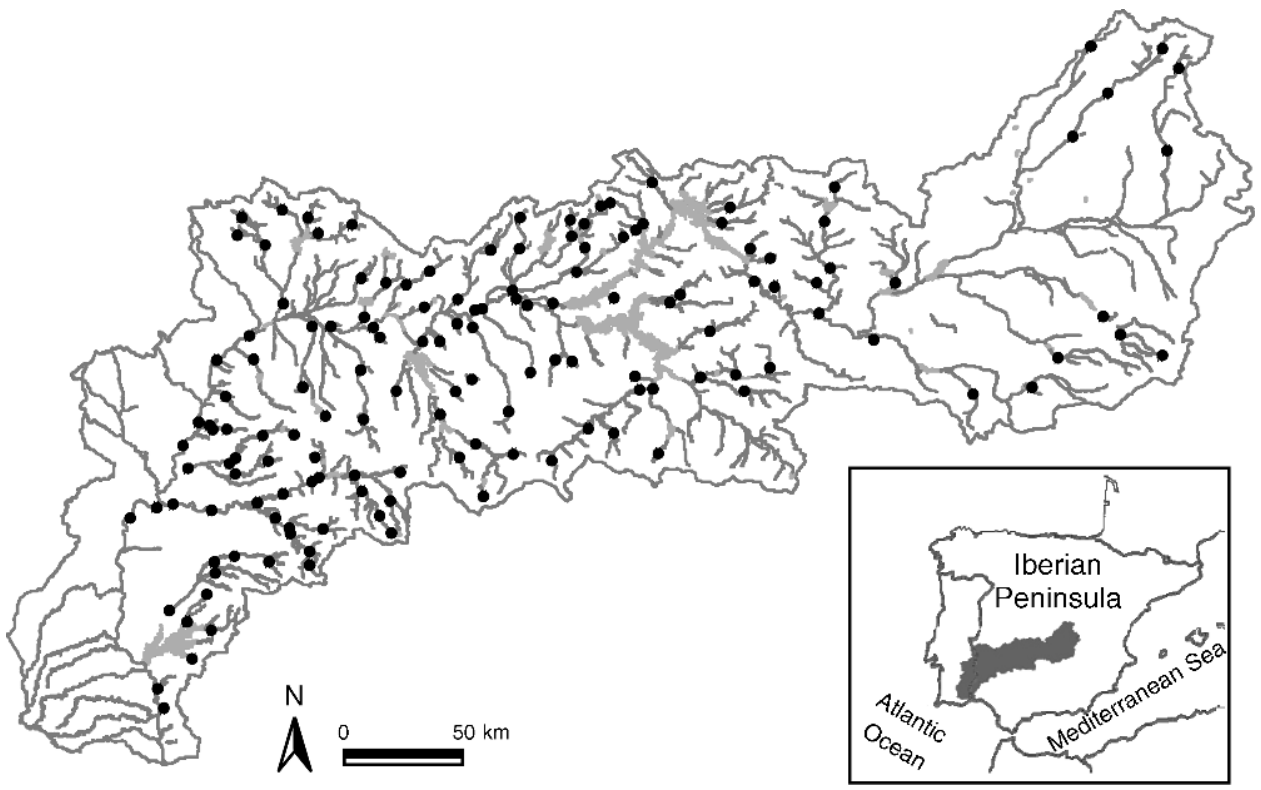

FIG. 2. Location of the Guadiana River basin in southwestern Iberian Peninsula and of 170 sites sampled for fish and habitat variables. 
TABLE 2. Environmental variables used to characterize sampled sites at two different scales.

\begin{tabular}{|c|c|c|c|c|c|}
\hline Variable & $\begin{array}{c}\text { Data } \\
\text { source }\end{array}$ & Method & Code & Mean & Range \\
\hline \multicolumn{6}{|l|}{ Site scale } \\
\hline Stream order (Strahler) & 1 & GIS & ORD & 2.1 & $1.0-6.0$ \\
\hline Distance to headwater $(\mathrm{km})$ & 1 & GIS & HED & 68.1 & $3.6-1036.1$ \\
\hline Distance to Guadiana River (km) & 1 & GIS & GUA & 58.2 & $0.0-196.0$ \\
\hline River width $(\mathrm{m}) \dagger$ & & in situ & WID & 10.8 & $1.4-123.0$ \\
\hline Riparian quality index $\uparrow+$ & & in situ & QBR & 61.8 & $0-100$ \\
\hline $\mathrm{NH}_{4}^{+}(\mathrm{mg} / \mathrm{L}) \dagger$ & & in situ & AMO & 1.4 & $0.0-51.6$ \\
\hline $\mathrm{NO}_{2}^{-}(\mathrm{mg} / \mathrm{L}) \dagger$ & & in situ & NTI & 0.1 & $0.01-2.00$ \\
\hline $\mathrm{NO}_{3}^{-}(\mathrm{mg} / \mathrm{L}) \dagger$ & & in situ & NTA & 4.1 & $0.5-55.9$ \\
\hline $\mathrm{PO}_{5}{ }^{3-}(\mathrm{mg} / \mathrm{L}) \dagger$ & & in situ & PHS & 1.0 & $0.1-23.2$ \\
\hline $\mathrm{SO}_{4}^{2-}(\mathrm{mg} / \mathrm{L}) \dagger$ & & in situ & SLF & 110.1 & $10.0-2380.0$ \\
\hline $\mathrm{Cl}^{-}(\mathrm{mg} / \mathrm{L}) \dagger$ & & in situ & CLR & 56.1 & $2.0-834.0$ \\
\hline Conductivity $(\mu \mathrm{S} / \mathrm{cm}) \dagger$ & & in situ & CND & 624.7 & $38.0-3230.0$ \\
\hline Annual precipitation $\left(\mathrm{mm} / \mathrm{m}^{2}\right)$ & 2 & GIS & PRE & 593.1 & $370.2-1114.5$ \\
\hline Average annual air temperature $\left({ }^{\circ} \mathrm{C}\right)$ & 2 & GIS & ATEM & 15.8 & $13.0-18.0$ \\
\hline $\begin{array}{l}\text { Distance to the nearest reservoir upstream } \\
(\mathrm{km}) \dagger\end{array}$ & 1 & GIS & DUP & 41.1 & $0.0-196.0$ \\
\hline $\begin{array}{l}\text { Distance to the nearest reservoir } \\
\text { downstream }(\mathrm{km}) \dagger\end{array}$ & 1 & GIS & DWN & 25.9 & $0.2-115.8$ \\
\hline \multicolumn{6}{|l|}{ Basin scale } \\
\hline $\begin{array}{l}\text { Basin area (drainage surface in each site, } \\
10^{3} \mathrm{~km}^{2} \text { ) }\end{array}$ & 3 & GIS & ARE & 260.1 & $0.9-5919.1$ \\
\hline $\begin{array}{l}\text { Gravelius index (area/perimeter, m) } \\
\text { Land use }\end{array}$ & 3 & GIS & GRA & 1.7 & $1.1-2.7$ \\
\hline Urban/industrial $(\%) \dagger$ & 4 & GIS & BUI & 0.4 & $0.0-6.7$ \\
\hline Intensive agriculture $(\%) \dagger$ & 4 & GIS & BIA & 22.5 & $0.0-97.0$ \\
\hline Extensive agriculture $(\%) \dagger$ & 4 & GIS & BEA & 11.0 & $0.0-89.1$ \\
\hline Natural $(\%) \dagger$ & 4 & GIS & BNA & 65.8 & $0.9-100.0$ \\
\hline Population density (inhabitants $\left./ \mathrm{km}^{2}\right) \dagger$ & 5 & GIS & POP & 21.0 & $0.0-459.3$ \\
\hline
\end{tabular}

Notes: Variables were recorded in situ or using digital maps in a GIS. Mean and total range values are shown.

Data sources: 1, stream network provided by the Confederación Hidrográfica del Guadiana; 2, Ninyerola et al. (2005); 3, digital elevation model 1:100.000 (Confederación Hidrográfica del Guadiana); 4, CORINE land cover 1:100.000 (Confederación Hidrográfica del Guadiana); 5, Instituto Nacional de Estadística, available online: 〈www.ine.es〉.

$\dagger$ Potentially human-perturbed variables.

† QBR (Munné et al. 2003).

integrity (ICI; Hermoso et al. 2010), which measures the general deviation of the observed assemblage composition from an expected assemblage in absence of major perturbations (human or biotic) following the reference condition approach (Hughes et al. 1986, Reynoldson et al. 1997, Bailey et al. 1998). Only native species were included in the index. We determined the reference assemblage composition (probability of occurrence of each species) using assessment by nearest neighbor analysis (ANNA; Linke et al. 2005). ANNA determines a set of the most environmentally similar reference sites for each target site, and predicts the assemblage composition based on the assemblage composition of the nearest neighbors (Linke et al. 2005). ANNA was used in this case since it simultaneously allows fitting multi-response models for most the species in the assemblage, allowing us to include species with prevalence $>5 \%$ (Table 1) in the model.

We built and validated our ANNA model with two independent sets of reference localities (construction and validation, 70 and 20 of reference localities each) using those environmental variables not affected by human perturbations as predictors (Appendix). Performance tests showed our ANNA model was valid and accurate, minimizing type I and II statistical errors (Hermoso et al. 2009a). We measured the deviation of the observed presences-absences from the expected probabilities (in absence of perturbations) for each species at each site obtaining 10 different residuals for a given site. Negative residual values indicated a loss of species (i.e., the species was predicted to be present with a certain probability but was actually absent), while positive residuals indicated observed presences with low predicted probabilities. Residuals were standardized ( $x$ - mean/ $\mathrm{SD}$ in the reference data set) and transformed into probabilities (ranging $0-1$ ), based on the cumulative normal distribution function corresponding to a given $x$ residual value (Pont et al. 2007). Final index scores were the sum of partial species probabilities. The index ranged between 10 (no biodiversity loss) and zero (complete biodiversity loss).

Two principal components analyses (PCAs) were carried out on a reduced set of environmental variables (Table 2) to obtain perturbation and natural gradients 
TABLE 3. Principal component analyses used to define anthropogenic disturbance and environmental gradients.

\begin{tabular}{|c|c|c|c|c|c|}
\hline Aim & Variables & $\begin{array}{l}\text { Extracted } \\
\text { gradients }\end{array}$ & $\begin{array}{c}\text { Variation } \\
\text { explained } \\
(\%, \text { eigenvalue })\end{array}$ & Negative extreme & $\begin{array}{l}\text { Positive } \\
\text { extreme }\end{array}$ \\
\hline \multirow[t]{2}{*}{$\begin{array}{l}\text { Identify perturbation } \\
\text { gradients }\end{array}$} & $\begin{array}{l}\text { All the perturbation } \\
\text { variables listed in } \\
\text { Table } 2\end{array}$ & $\mathrm{PC} 1_{\text {deg }}$ & $34.7(3.13)$ & $\begin{array}{l}\text { NTOT }(-0.64), \text { CLR }(-0.67), \\
\text { SLF }(-0.55), \text { PHS }(-0.50), \\
\text { CND }(-0.71), \text { BUI }(-0.55), \\
\text { BIA }(-0.63), \operatorname{POP}(-0.54)\end{array}$ & QBR (0.48) \\
\hline & & $\mathrm{PC} 2_{\mathrm{deg}}$ & $22.1(5.39)$ & $\begin{array}{l}\text { PHS }(-0.67), \text { SLF }(-0.57) \\
\quad \text { POP }(-0.64), \text { QBR }(-0.35)\end{array}$ & \multirow[t]{2}{*}{$\begin{array}{l}\text { SFL }(0.62) \\
\text { BIA }(0.39) \\
\text { CND }(0.34)\end{array}$} \\
\hline $\begin{array}{l}\text { Identify natural } \\
\text { gradients }\end{array}$ & $\begin{array}{l}\text { All the environ- } \\
\text { mental variables } \\
\text { listed in Table } 2, \\
\text { not related to } \\
\text { human } \\
\text { perturbation }\end{array}$ & $\mathrm{PCl}_{\text {nat }}$ & $50.5(1.99)$ & $\begin{array}{l}\text { HED }(-0.96), \text { ARE }(-0.96), \\
\text { GRA }(-0.80) \text {, ATEM }(-0.40), \\
\text { ORD }(-0.88)\end{array}$ & \\
\hline
\end{tabular}

Notes: Only loadings $>0.34$ are shown. Variable codes are shown in Table 2. NTOT represents the sum of AMO, NTI, and NTA.

to be used as predictors. The first PCA was carried out on variables related to human perturbations (Table 2) and produced two PCs that accounted for $56.9 \%$ of the total variation in the perturbation variables. The first $\mathrm{PC}$ (denoted as $\mathrm{PC}_{\mathrm{deg}}$ ) represented the general perturbation status related to land-use, riparian forest alteration and water quality degradation (Table 3 ). The second PC $\left(\mathrm{PC} 2{ }_{\mathrm{deg}}\right)$ discriminated sites affected by agriculture from those with urban derived impacts (Table 3). A second PCA was performed on environmental variables representing natural gradients. The resulting first $\mathrm{PC}\left(\mathrm{PC}_{\text {nat }}\right)$ explained half of the original variation $(50.5 \%)$ and was mainly related to the natural longitudinal upstreamdownstream gradient (Table 3). The three PCs were later used as surrogates of human perturbation or natural gradients in the analyses.

We also included the upstream or downstream distance from a site to the nearest reservoir $(\mathrm{km})$ as a predictor in our analyses, considering the potential effect of the establishment and dispersion of invasive species (Johnson et al. 2008). The abundance of invasive species ([log [CPUE +1]-transformed), was used to account for the effect of invasive species on native fish assemblages. A preliminary analysis on the tolerance of our predictor variables suggested they were not redundant (Pearson's $R<0.2$ in all possible cross-correlations between predictor variables).

\section{Invasive species: drivers or passenger in the process of natives' decline?}

The driver or passenger role of invasive species in the decline of native freshwater fish assemblages was explored through two different approaches. First, we built all possible multiple regression models between our response variables (biotic integrity and native species richness) and the set of predictors. These models included a full model with all the predictors, single models for each predictor and all possible combinations of multi-variable models. Models were ranked according to their Akaike's information criterion (AIC), and each model's support was estimated through the difference in AIC with respect to the top-ranked model ( $\triangle \mathrm{AIC})$. AIC estimates the distance between a certain model and the (unknown) theoretical underlying mechanism generating the data. Lower AIC values indicate better fit (Burnham and Anderson 2002). We inspected all models having moderate support (i.e., $\triangle \mathrm{AIC}<7$ in relation to the bestranking model, according to Burnham and Anderson 2002). For these models we first calculated their Akaike weights $\left(w_{i}\right)$ as the ratio of each model's likelihood to the sum of all the model likelihoods (Burnham and Anderson 2002). Then we used the cumulative Akaike weights $\left(\Sigma w_{i}\right)$ as a measure of predictor importance (Burnham and Anderson 2002). The $\Sigma w_{i}$ for each predictor was assessed as the sum of $w_{i}$ for all the models where it was included. We would expect a high relative importance of invasive species if they had an active role in native species decline instead of being passengers.

Additionally, structural equation modeling (SEM; Bollen 1989) was used to simultaneously model combinations of our variables as predictors and responses (Gerbin and Anderson 1988). This is an advance with respect to multiple regression analyses, which can only analyze a single layer of linkages between response and predictor variables at a time. Whereas the direct impacts of individual drivers can be readily recognized, indirect causal linkages among multiple drivers can be difficult to detect and quantify. SEM is a common technique used to deal with the analysis of many drivers of ecological change that could be acting at the same time, and that might be too complex to test experimentally (Wootton 1994, Didham et al. 2005). SEM also allows testing multiple relationships between the set of variables under consideration, placing more accurately the target variables (invasive species) within the complex matrix of relationships.

We used SEM to test the role of invasive species as drivers or passengers in the decline of native fish assemblages through the comparison of three alternative models (full, driver, and passenger). The full model 
Biotic integrity

A) Full model

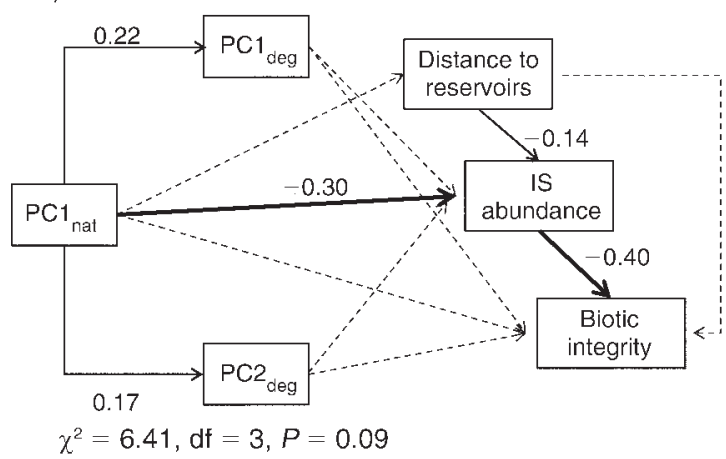

B) Driver model

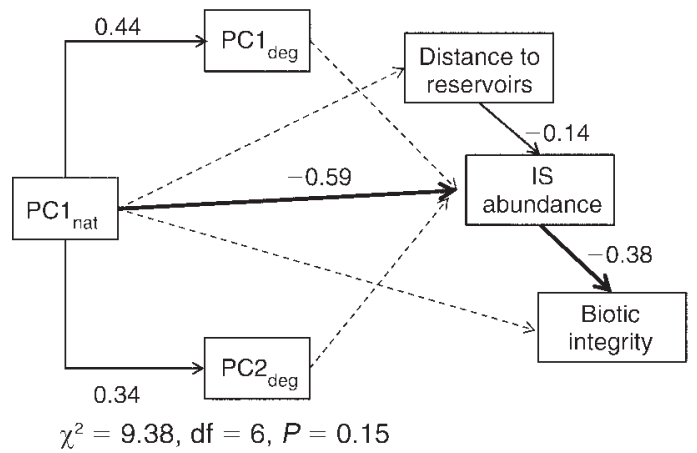

C) Passenger model

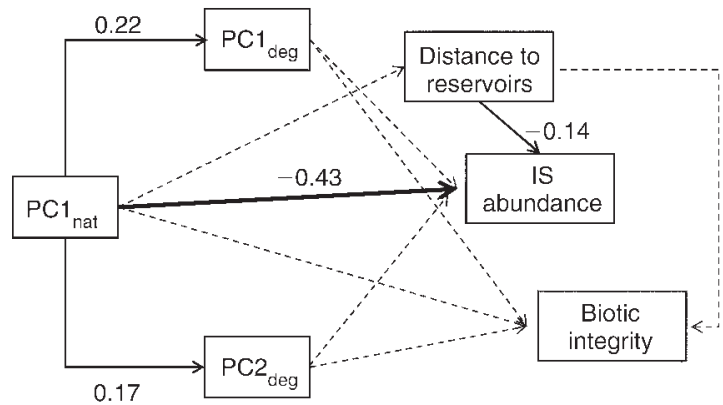

$\chi^{2}=32.24, \mathrm{df}=5, P<0.001$
Native richness
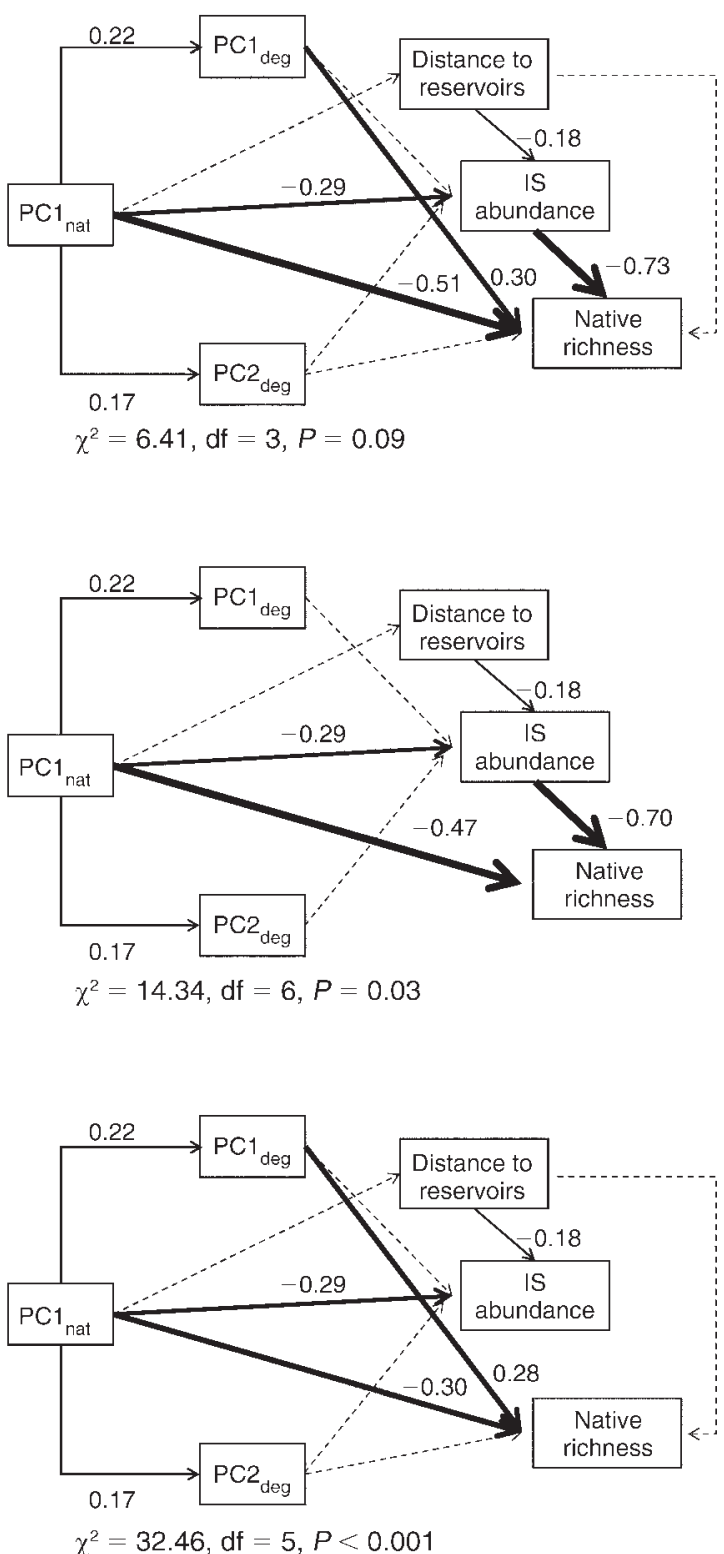

FIG. 3. Scheme of different structural equation models testing alternative pathways of invasive species (IS) and habitat degradation on natives' decline (Fig. 1). In the driver model we assumed that the abundance of invasive species is leading the process of biodiversity loss (measured using an index of biotic integrity and native species richness), whereas in the passenger model habitat degradation has the leading role. The full model includes all potential paths between the variables considered. Standardized coefficients based on the correlation matrix for each path are shown. Dotted lines represent nonsignificant effects, and line thickness is proportional to their relative weight. The chi-square statistic (testing significant differences between the observed and expected covariance matrices), degrees of freedom (df), and $P$ (based on likelihood-ratio test) are also shown. Significant differences $(P<$ 0.05 ) indicate poor fit between the tested model and the observed data. Variable codes are listed in Table 3.

(Fig. 3A) included relationships between all variables and was used as the baseline for comparison with the other two nested models (driver and passenger). The driver model (Fig. 3B) only considered direct effects of $\mathrm{PC}_{\text {nat }}$ and the abundance of invasive species on biotic integrity/native species richness, while habitat degra- dation $\left(\mathrm{PC}_{\mathrm{deg}}\right.$ and $\left.\mathrm{PC} 2_{\mathrm{deg}}\right)$ and reservoirs had only indirect effects via invasive species. The passenger model (Fig. 3C) assumed direct effects of habitat degradation and natural gradients on biotic integrity/ native species richness and excluded effects of invasive species. 
Within SEMs, hypotheses are translated into a series of regression equations that can be solved simultaneously to generate estimated covariance matrices. These matrices depend not only on the identity of the variables included in the models, but also on the interactions between variables that are being tested. Each estimated matrix is compared to the observed sample covariance/ correlation matrix by means of a goodness-of-fit index (Bollen 1989) to determine whether the hypothesized model is an acceptable representation of the data. We used the likelihood ratio test to determine the probability that the observed and expected covariance matrices (under the models constrictions) differ by more than would be expected due to random sampling errors (Mitchell 1993, Shipley 2000). If the data are consistent with the model specified, no significant differences between the observed and expected covariance matrices are expected. We considered an alpha value of 0.05 to determine statistical significance.

\section{Invasive-native species relationships along environmental gradients}

We tested whether the functional relationship between native assemblages and invasive species (sensu Didham et al. 2007) changed along environmental gradients or, in other words, whether the effect of invasive species was constant along those gradients or if habitat perturbation enhanced or reduced the effect of invasive species (synergic effects). We used analyses of covariance (ANCOVA) with the abundance of invasive species as a covariate to test the homogeneity of slopes of the relationship between dependent variables (biotic integrity or native species richness) and each perturbation $\left(\mathrm{PC}_{\mathrm{deg}}\right.$ and $\left.\mathrm{PC} 2_{\mathrm{deg}}\right)$ and natural $\left(\mathrm{PC}_{\text {nat }}\right)$ gradient, as well as along increasing distances to reservoirs. To allow the use of continuous variables as factors, PC gradients and distances to reservoirs were categorized into four equal-sized levels. The possible changes in the functional relationship between invasive species and native assemblages were tested using homogeneity slope tests (García-Berthou and Moreno-Amich 1993). Significant results of the covariate $\times$ factor interaction terms would imply changes in the per capita impacts (i.e., slopes) of invasive fish, whereas nonsignificant results (i.e., constant slopes along environmental gradients) would denote simple numerically mediated responses of native assemblages to invasive species. Whenever the interaction term from the homogeneity of slopes test was not statistically significant $(P>0.10$, sensu García-Berthou and Moreno-Amich 1993), it was deleted from the models, and standard ANCOVA analyses were run. Different generalized linear model (GLZ) configurations were used for each response variable. A normal distribution with an identity link function was used for the index of biotic integrity (normally distributed) whereas a Poisson distribution with a log link function was used for species richness (count variable).

\section{Results \\ Invasive species: drivers or passenger of native species decline?}

The top-ranked multiple regression model using biotic integrity as the response variable included invasive species abundance as the only predictor. The remaining models with moderate support $(\triangle \mathrm{AIC}<7)$ showed similar information, representing all possible combinations between the abundance of invasive species and the other predictor variables. This means that the inclusion of the abundance of invasive species was essential for a model to receive moderate support. All models showed a low adjusted $R^{2}$ though. Based on the likelihood ratio test, the abundance of invasive species was the only variable included as a significant predictor in all models (Table 4). The top-ranked model for native species richness included all the predictors except distance to reservoirs (Table 4). Abundance of invasive species appeared with a significant negative effect in all 10 of the models with moderate support $(\triangle \mathrm{AIC}<7)$, whereas the natural gradient $\left(\mathrm{PC}_{\text {nat }}\right)$ appeared as a significant term in eight of them (Table 4). Both predictors had high cumulative $\Sigma w_{i}$ (1.00 and 0.95 , for invasives abundance and $\mathrm{PCl}_{\text {nat }}$, respectively), followed in importance by $\mathrm{PC} 2_{\text {deg }}$ and $\mathrm{PC} 1_{\text {deg }}(0.80$ and 0.67 , respectively).

The goodness of fit test indicated the full and driver models were consistent with the data for biotic integrity, since the difference in the observed and expected covariation matrices was not statistically significant $(P$ $=0.09$ and $P=0.15$ for the full and driver model, respectively). The full model was also consistent explaining native richness, while the driver was not $(P$ $=0.09$ and $P=0.03$ for the full and driver model, respectively). On the other hand, the passenger model, in which the effect of invasives abundance on native assemblages had not been included, was inconsistent in both cases $(P<0.001$, Fig. 3$)$.

SEM analyses revealed a strong effect of the abundance of invasive species on biotic integrity and native species richness, and natural upstream-downstream gradient on both invasive species abundance and native species richness. The latter effect was not detected for biotic integrity since it was previously accounted in the assessment of the index of biotic integrity. The longitudinal gradient was considered using the reference condition approach when comparing the observed and expected native assemblages. The expected species composition in reference condition for each site was obtained including environmental variables describing this longitudinal gradient in the predictive model (variables listed in Table 1 not affected by human perturbations) so the spatial location of each site was considered in the comparison. The distance to the nearest reservoir also showed significant effects on the abundance of invasive species (and thus indirectly on natives), as well as the natural gradient on both perturbation gradients $\left(\mathrm{PC}_{\mathrm{deg}}\right.$ and $\mathrm{PC} 2_{\mathrm{deg}}$; Fig. 3). 
TABLE 4. Summary of multiple regression models with moderate support predicting biotic integrity and native species richness $(\triangle \mathrm{AIC}<7)$.

\begin{tabular}{|c|c|c|c|c|c|c|c|}
\hline Model rank & IS abundance & $P C 1_{\text {deg }}$ & $\mathrm{PC} 2_{\text {deg }}$ & $\mathrm{PC}_{\text {nat }}$ & $\begin{array}{l}\text { Distance to } \\
\text { reservoir }\end{array}$ & $\Delta \mathrm{AIC}$ & $w_{i}$ \\
\hline \multicolumn{8}{|l|}{ Biotic integrity } \\
\hline 1 & $-0.432 * *$ & & & & & & 0.15 \\
\hline 2 & $-0.444^{* *}$ & & & & -0.117 & 0.92 & 0.10 \\
\hline 3 & $-0.438^{* *}$ & & -0.076 & & & 0.96 & 0.09 \\
\hline 4 & $-0.429^{* *}$ & 0.083 & & & & 1.04 & 0.09 \\
\hline 5 & $-0.453 * *$ & & & -0.069 & & 1.17 & 0.08 \\
\hline 6 & $-0.456^{* *}$ & 0.103 & & -0.093 & & 1.72 & 0.06 \\
\hline 7 & $-0.469^{* *}$ & & & -0.081 & -0.128 & 1.90 & 0.06 \\
\hline 8 & $-0.435^{* *}$ & 0.083 & -0.076 & & & 1.99 & 0.06 \\
\hline 9 & $-0.449 * *$ & & -0.071 & & -0.112 & 2.02 & 0.06 \\
\hline 10 & $-0.440^{* *}$ & 0.068 & & & -0.101 & 2.23 & 0.05 \\
\hline 11 & $-0.455^{* *}$ & & -0.068 & -0.059 & & 2.32 & 0.05 \\
\hline 12 & $-0.470 * *$ & 0.088 & & -0.099 & -0.110 & 2.77 & 0.04 \\
\hline 13 & $-0.458^{* *}$ & 0.100 & -0.064 & -0.082 & & 2.92 & 0.04 \\
\hline 14 & $-0.471^{* *}$ & & -0.060 & -0.071 & -0.122 & 3.20 & 0.03 \\
\hline 15 & $-0.445^{* *}$ & 0.069 & -0.071 & & -0.095 & 3.30 & 0.03 \\
\hline 16 & $-0.471^{* *}$ & 0.086 & -0.058 & -0.089 & -0.104 & 4.10 & 0.02 \\
\hline$\Sigma w_{i}$ & 1.00 & 0.38 & 0.37 & 0.38 & 0.38 & & \\
\hline \multicolumn{8}{|l|}{ Native richness } \\
\hline 1 & $-0.720 * *$ & 0.304 & -0.194 & $-0.509 * *$ & & & 0.37 \\
\hline 2 & $-0.711^{* *}$ & & -0.205 & $-0.438 * *$ & & 1.49 & 0.18 \\
\hline 3 & $-0.726^{* *}$ & 0.298 & -0.191 & $-0.513 * *$ & -0.047 & 1.93 & 0.14 \\
\hline 4 & $-0.713^{* *}$ & 0.312 & & $-0.542 * *$ & & 2.72 & 0.10 \\
\hline 5 & $-0.725^{* *}$ & & -0.198 & $-0.449 * *$ & -0.110 & 3.38 & 0.07 \\
\hline 6 & $-0.704^{* *}$ & & & $-0.471 * *$ & & 4.25 & 0.04 \\
\hline 7 & $-0.722^{* *}$ & 0.303 & & $-0.546^{* *}$ & -0.066 & 4.64 & 0.04 \\
\hline 8 & $-0.720^{* *}$ & & & $-0.482 * *$ & -0.130 & 6.10 & 0.02 \\
\hline 9 & $-0.586^{* *}$ & & -0.270 & & & 6.28 & 0.02 \\
\hline 10 & $-0.579^{* *}$ & 0.197 & -0.269 & & & 6.72 & 0.01 \\
\hline$\Sigma w_{i}$ & 1.00 & 0.67 & 0.80 & 0.95 & 0.28 & & \\
\hline
\end{tabular}

Notes: The set of environmental and perturbation gradients described in Table 3 and the distance to the nearest reservoir were used as predictors (adjusted $R^{2}=0.13$ and 0.17 , respectively, for the biotic integrity and native richness models). Their cumulative Akaike weights $\left(\Sigma w_{i}\right)$ used to measure each predictor's relative importance are shown. IS stands for invasive species.

** Significant effect $(P<0.01)$ of regression coefficient based on the likelihood ratio test.

$P C 1_{\text {deg }}$ only had significant effects on native species richness while $\mathrm{PC} 22_{\mathrm{deg}}$ showed no significant effect on native assemblages or invasive species abundance.

\section{Invasive-native species relationships along environmental gradients}

The slope of the relationship between the abundance of invasive species and both biotic integrity and native species richness was strikingly constant along the natural and perturbation gradients (Fig. 4 and Table 5). In all cases, the abundance of invasive species had a negative effect on biotic integrity and native species richness, denoting the clear impact of invasive species on both variables (Fig. 4). PC1 $1_{\text {nat }}$ and $\mathrm{PC} 2_{\text {deg }}$ also had significant effects on native species richness (Table 5), which tended to increase toward downstream localities and was higher in agricultural areas than in urbanized ones.

\section{Discussion}

Our results suggest that biotic interactions with invasive species are the leading driver of the decline of native freshwater fish assemblages in the Guadiana
River. We detected few direct effects of habitat degradation on native assemblages, whereas the negative relationships between native and invasive species remained constant along habitat degradation gradients. The role of invasive species driving the decline of native species had already been reported in our study area, but was not clearly distinguished from habitat degradation (Godinho and Ferreira 1998, Corbacho and Sánchez 2001). Corbacho and Sánchez (2001) found habitat degradation reduced the number of native species and increased the number of invasive species in the Guadiana River basin. They concluded that habitat degradation might be the leading cause of both the decline of natives and the proliferation of invasive species. Godinho and Ferreira (1998) also highlighted the role of invasive species explaining native assemblage composition after accounting for the effect of natural environmental gradients. However, this study lacked the inclusion of habitat perturbation as predictors, and did not measure the effect of potential interaction pathways between invasive species and habitat degradation.

Our results show that the abundance of invasive species was a key variable explaining both native species 

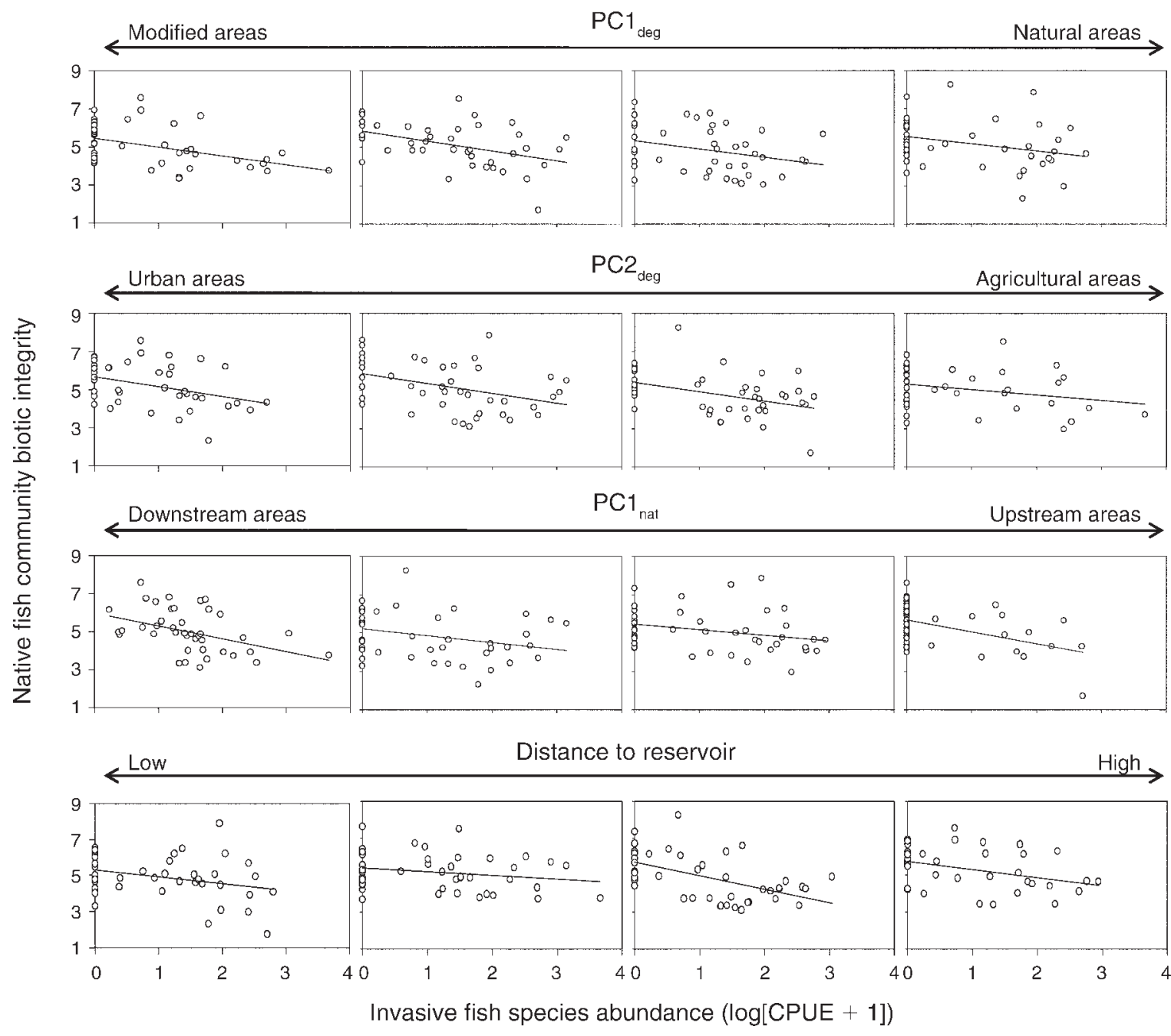

FIG. 4. Relationship between the abundance of invasive species (covariate) and biotic integrity (predictor) along natural and perturbation gradients (factors). Each plot represents a portion of the gradient, corresponding to the four equivalent categories in which the gradients described in Table 3 and the distance to the nearest reservoir were split for the ANCOVAs. Variables codes are listed in Table 3.

richness and biotic integrity. The driver model was the most parsimonious model explaining the biotic integrity of native fish assemblages, while the full model was the most suitable for explaining species richness. The driver model assumed only direct effects of the abundance of invasive species on natives, with habitat degradation and the distance to the nearest reservoir having only indirect effects via their relationships with the abundance of invasive species. When all the interaction pathways were considered in the full model neither the perturbation nor the longitudinal gradients were significant in the case of biotic integrity, while $\mathrm{PC}_{\mathrm{deg}}$ and $\mathrm{PC}_{\text {nat }}$ showed significant effects explaining native species richness. In all cases (driver and full models for biotic integrity and species richness) invasive species had the stronger direct effect as the magnitude of its standardized regression parameters indicated (Fig. 3). In the latter case the relationship between $\mathrm{PC}_{\text {nat }}$ and $\mathrm{PC}_{\mathrm{deg}}$ could be behind the significant effect of $\mathrm{PCl}_{\text {deg }}$ on native species richness. Actually, when the effect of the longitudinal gradient was accounted for in the index of biotic integrity, $\mathrm{PC}_{\mathrm{deg}}$ was not significant. More importantly, the passenger model, which did not consider the effects of invasive species on native assemblages and only included the effect of habitat degradation or natural gradients, did not fit our data.

While our models are robust, we cannot exclude the possibility that observed fish biodiversity patterns, may be related to sources of habitat degradation not considered in this study (Shipley 2000). This may be the case when there are increased effects of summer drought due to water impoundment and diversion for agricultural uses. We were unable to include this effect at the scale of our analyses, yet it could have a strong effect on both native and invasive fish assemblages particularly when considering the high rate of water diversion in 
some areas of the basin (Formes et al. 2000, Cortina and Cruces 2005).

The driver role of invasive species has been previously reported in California (with a similar Mediterranean climate), and was the main factor leading to freshwater fish imperilment at the watershed scale (Light and Marchetti 2006). That study highlighted the positive relationship between non-indigenous species richness and the level of imperilment of fish assemblages, measured as the number of species of conservation concern while accounting for total native richness. Moreover the authors also found that hydrologic modifications and development had only indirect effects on native communities through the relationship of these factors with invasive species. Some other studies in the same region, although using different approaches, back up the idea that modified habitats continue holding native species in the absence of invasions (Baltz and Moyle 1993, Moyle 2002). Our results complement those in California and suggest that Mediterranean freshwater fish assemblages may be relatively resistant to habitat perturbations, but are highly sensitive to the impacts of invasive species (Baltz and Moyle 1993, Moyle 2002).

None of the habitat gradients used as factors in the ANCOVA analysis influenced the association between invasive species abundance and native species richness or biotic integrity. The mechanism of action of invasive species on native assemblages in our study area can be thus interpreted as a numerically mediated process, and any factor enhancing the proliferation of invasive species would negatively influence native freshwater fish assemblages. We found that the natural upstreamdownstream gradient and the distance to reservoirs were the only environmental features with significant effects on the abundance of invasive species, which increased downstream and near reservoirs (see Fig. 3). These patterns strongly suggest that habitat stability, which is higher close to reservoirs and at low reaches (Godinho et al. 1997, Magalhães et al. 2002, Clavero et al. 2004), is an important environmental factor regulating the colonization and expansion success of invasive species.

Habitat stability is a critical factor structuring fish assemblages (Schlosser 1987, Jackson et al. 2001, McGarvey and Hughes 2008), and is especially important where water availability is a limiting resource. This is the case of Mediterranean streams, which experience extremes in both intra- and interannual seasonality in water availability (Gasith and Resh 1999). Permanent waters are essential refuges during summer droughts, when small streams or headwaters are often desiccated (Magalhães et al. 2002). Mediterranean freshwater fish evolved in highly unstable systems and tend to be habitat generalists that are well adapted to survive in constantly changing environments (Clavero et al. 2004). However, there is a clear natural gradient of native species richness and abundance change from upstream to downstream. Both species richness and abundance tend to increase toward downstream reaches in response
TABLE 5. Results of partial ANCOVAs testing the effect of invasive species abundance on native species richness or biotic integrity.

\begin{tabular}{|c|c|c|c|}
\hline Factors & Wald & $\mathrm{df}$ & $P$ \\
\hline \multicolumn{4}{|l|}{ Biotic integrity } \\
\hline IS abundance & 27.5 & 1 & $<0.001$ \\
\hline$P C 1_{\text {deg }}$ & 3.6 & 3 & 0.577 \\
\hline Interaction & $(0.4)$ & (3) & $(0.948)$ \\
\hline IS abundance & 25.7 & 1 & $<0.001$ \\
\hline $\mathrm{PC} 2_{\mathrm{deg}}$ & 3.9 & 3 & 0.271 \\
\hline Interaction & $(1.5)$ & (3) & $(0.689)$ \\
\hline IS abundance & 24.0 & 1 & $<0.001$ \\
\hline $\mathrm{PCl}_{\text {nat }}$ & 2.7 & 3 & 0.404 \\
\hline Interaction & $(2.9)$ & (3) & $(0.406)$ \\
\hline IS abundance & 25.3 & 1 & $<0.001$ \\
\hline Distance to reservoirs & 4.4 & 3 & 0.224 \\
\hline Interaction & $(5.5)$ & (3) & $(0.139)$ \\
\hline \multicolumn{4}{|l|}{ Native richness } \\
\hline IS abundance & 10.0 & 1 & $<0.001$ \\
\hline$P C 1_{d e g}$ & 3.6 & 3 & 0.312 \\
\hline Interaction & $(0.5)$ & (3) & $(0.926)$ \\
\hline IS abundance & 9.4 & 1 & $<0.001$ \\
\hline $\mathrm{PC} 2_{\mathrm{deg}}$ & 13.4 & 3 & 0.003 \\
\hline Interaction & $(0.9)$ & (3) & $(0.821)$ \\
\hline IS abundance & 12.6 & 1 & $<0.001$ \\
\hline $\mathrm{PC} 1_{\text {nat }}$ & 8.5 & 3 & 0.030 \\
\hline Interaction & $(1.8)$ & (3) & $(0.625)$ \\
\hline IS abundance & 7.8 & 1 & 0.005 \\
\hline Distance to reservoirs & 2.1 & 3 & 0.553 \\
\hline Interaction & $(4.8)$ & (3) & $(0.185)$ \\
\hline
\end{tabular}

Notes: Environmental gradients were categorized into factors (see Methods for details). When nonsignificant $(P>0.1)$, interaction terms (in parentheses) were removed from final models.

to the increase in living space and environmental stability (Magalhães et al. 2002). Most invasive fish species introduced to Iberian freshwaters occupy stable habitats, often lentic systems (Corbacho and Sánchez 2001, Elvira and Almodóvar 2001, Ribeiro et al. 2008), and few of them are able to cope with the extreme flow fluctuations in small Mediterranean streams (VilaGispert et al. 2005). The milder environmental fluctuations that occur in reservoirs, and their proximities, and in downstream reaches would favor the successful establishment of invasive species populations (Moyle and Light 1996, Corbacho and Sánchez 2001, Ribeiro et al. 2008). Therefore, habitat stability appears to play an essential role for both native and invasive species populations in Mediterranean streams, whereas the proliferation of invasives in these environments may endanger the natural resilience of native assemblages. In fact, the impacts of invasive species in our study area blurred the natural increase of native species downstream, which was evident only when the effects of invasive species had been taken into account. This means that the impacts of invasive species are especially strong in areas that should bear the richest native fish assemblages within the basins and that could act as population refuges during extreme climatic events (e.g., prolonged droughts). 
Over the past century, human activity has promoted invasions both by creating new transport vectors and by changing natural habitats. Creation of impoundments is a clear example of this trend, promoting invasions by increasing colonization opportunities for nonindigenous taxa and by enhancing their subsequent establishment success (Shea and Chesson 2002, Clavero et al. 2004, Havel et al. 2005, Johnson et al. 2008). Reservoirs cause a drastic reduction of habitat heterogeneity, not only converting extensive reaches of stream habitat into standing water, but also altering the downstream magnitude and timing of water flows, sediment load and creating barriers for fish migration (Malmqvist and Rundle 2002). Our results suggest that reservoirs do not play a direct significant role in the decline of native fish assemblages in the Iberian Peninsula. However, they have indirect effects through their relationship with invasive species. Propagule pressure is a major factor for predicting the success of invaders in colonizing new ecosystems (Kolar and Lodge 2000) and reservoirs play an important role as centers of introduction of invasive species (Clavero et al. 2004, Havel et al. 2005, Johnson et al. 2008).

The driver and passenger models have different implications for conservation policies and practices. Our analyses showed that invasive species are the leading cause of native fish decline, while habitat degradation neither affected directly biotic integrity nor influenced the per capita effect of invasive species. Therefore, management plans should be focused on controlling invasive species. The most effective manner of addressing the invasion of nonnative species to fresh waters is to prevent active and accidental introductions (Myers et al. 2000), but little effort has been devoted to reduce the risk of new introductions. While humanmediated species introductions have occurred for centuries, the rate of new introductions has increased dramatically during the last century (Lozon and MacIsaac 1997). In the Iberian Peninsula, the number of introduced fish species is continually rising and established invasive species are spreading through both natural expansion and secondary introductions allowing interbasin jump dispersal (Clavero and García-Berthou 2006). Reduction in the current rate of new introductions should be based on proper legislation, regulation and public education, although the efficiency of such measures has not been tested. We suggest that wherever invasive species have already become established, active management is needed to reduce harmful effects and prevent further spread (Saunders et al. 2002). This is particularly true in highly sensitive areas holding healthy native assemblages.

There are several management approaches that could be followed in highly sensitive habitat areas: (1) eradication or long-term control of invasives at key times of year (Wittenberg and Cock 2001, MorenoValcárcel 2006); (2) extend flows in regulated rivers, given that previous studies suggest that the success of invasive species could be reversible if natural flow regimes are restored (Marchetti and Moyle 2000, 2001, Trexler et al. 2000) and (3) reduce dispersal rates from reservoirs (Rischbieter 2000). Eradication is the most cost-effective way to tackle the problem, although it can only be recommended when it is ecologically feasible (high probabilities of extirpation with low effects on native assemblages) and has enough financial support. However, where eradication is not feasible (the species is highly widespread or the eradication methods can have negative effects on natives), the other alternatives should be considered. Invasive species control programs should focus on the areas of highest value for native biodiversity and those most at risk from non-native invaders (Saunders et al. 2002). In this sense, further efforts should be devoted to the identification of those areas. Given the special role that reservoirs seem to play in the dispersion of invasive species, these environments should be a focus of attention in future management programs.

\section{ACKNOWLEDGMENTS}

The fieldwork was funded by the Confederación Hidrográfica del Guadiana through the project "Diseño y Explotación de la Red de Control Biológico de la Cuenca del Río Guadiana" and the Ministry of Science and Technology (REN2002-03513, CGL2005-02699). V. Hermoso held a predoctoral fellowship funded by the Spanish Ministry of Education (MEC) (AP-2004-1414). M. Clavero benefited from a Juan de la Cierva contract also funded by MEC. The authors also thank Stephanie Januchowski, Matthew Spencer, and two anonymous referees for their constructive comments on an earlier version of this paper.

\section{Literature Cited}

Allan, J. D., and A. S. Flecker. 1993. Biodiversity conservation in running waters. Identifying the major factors that threaten destruction of riverine species and ecosystems. BioScience 43: $32-43$.

Angermeier, P. L., and I. J. Schlosser. 1989. Species-area relationships for stream fishes. Ecology 70:1450-1462.

Bailey, R. C., M. G. Kennedy, M. Z. Dervish, and R. M. Taylor. 1998. Biological assessment of freshwater ecosystems using a reference approach: comparing predicted and actual benthic invertebrate assemblages in Yukon streams. Freshwater Biology 39:765-774.

Baltz, D. M., and P. B. Moyle. 1993. Invasion resistance to introduced species by a native assemblage of California stream fishes. Ecological Applications 3:246-255.

Bertrand, K. N., K. B. Gido, and C. S. Guy. 2006. An evaluation of single-pass versus multiple-pass backpack electrofishing to estimate trends in species abundance and richness in prairie streams. Transactions of the Kansas Academy of Science 109:131-138.

Bollen, K. A. 1989. Structural equations with latent variables. John Wiley, New York, New York, USA.

Burnham, K. P., and D. R. Anderson. 2002. Model selection and multimodel inference: a practical information-theoretic approach. Springer-Verlag, New York, New York, USA.

Clavero, M., F. Blanco-Garrido, and J. Prenda. 2004. Fish fauna in Iberian Mediterranean basins: biodiversity, introduced species and damming impacts. Aquatic Conservation: Marine and Freshwater Ecosystems 14:575-585.

Clavero, M., and E. García-Berthou. 2005. Invasive species are a leading cause of animal extinction. Trends in Ecology and Evolution 20:110. 
Clavero, M., and E. García-Berthou. 2006. Homogenization dynamics and introduction routes of invasive freshwater fish in the Iberian Peninsula. Ecological Applications 16:23132324.

Collares-Pereira, M. J., and I. G. Cowx. 2004. The role of catchment scale environmental management in freshwater fish conservation. Fisheries Management and Ecology 11: 303-312.

Corbacho, C., and J. M. Sánchez. 2001. Patterns of species richness and introduced species in native freshwater fish faunas of a Mediterranean-type basin: the Guadiana River (southwest Iberian Peninsula). Regulated Rivers: Research and Management 17:699-707.

Cortina, L. M., and J. Cruces. 2005. The analysis of the intensive use of groundwater in the upper Guadiana Basin (Spain) using a numerical model. Groundwater Intensive Use 7:285-294.

Cowx, I. G. 2002. Analysis of threats to freshwater fish conservation: past and present challenges. Pages 201-220 in M. J. Collares-Pereira, I. G. Cowx, and M. M. Coelho, editors. Conservation of freshwater fishes: options for the future. Fishing New Books, Blackwell Science, Oxford, UK.

Didham, R. K., J. M. Tylianakis, N. J. Gemmell, T. A. Rand, and R. M. Ewers. 2007. Interactive effects of habitat modification and species invasion on native species decline. Trends in Ecology and Evolution 22:489-496.

Didham, R. K., J. M. Tylianakis, M. A. Hutchinson, R. M. Ewers, and N. J. Gemmell. 2005. Are invasive species the drivers of ecological change? Trends in Ecology and Evolution 20:470-474.

Dudgeon, D., A. H. Arthington, M. O. Gessner, Z. Kawabata, D. J. Knowler, C. Lévêque, R. J. Naiman, A. H. PrieurRichard, D. Soto, M. L. J. Stiassny, and C. A. Sullivan. 2006. Freshwater biodiversity: importance, threats, status and conservation challenges. Biological Reviews 81:163-182.

Elvira, B., and A. Almodóvar. 2001. Freshwater fish introductions in Spain: facts and figures at the beginning of the 21st century. Journal of Fish Biology 59:323-331.

FAME Consortium. 2004. Manual for application of the European Fish index-EFI. Version 1.1, January 2005. European Commission, Brussels, Belgium.

Fazey, I., J. Fischer, and D. B. Lindenmayer. 2005. What do conservation biologists publish? Biological Conservation 124: 63-73.

Formes, J., J. A. Rodriguez, M. Hernandez, and M. R. Llamas. 2000. Possible solutions to avoid conflicts between water resources development and wetaland conservation in the "La Mancha Húmeda" Biosphere Reserve (Spain). Physics and Chemistry of the Earth, Part B: Hydrology, Oceans and Atmosphere 25:623-627.

García-Berthou, E., and R. Moreno-Amich. 1993. Multivariate analysis of covariance in morphometric studies of the reproductive cycle. Canadian Journal of Fish and Aquatic Science 50:1394-1399.

Gasith, A., and V. H. Resh. 1999. Streams in Mediterranean climate regions: abiotic influences and biotic responses to predictable seasonal events. Annual Review of Ecology and Systematics 30:51-81.

Gerbin, D. W., and J. C. Anderson. 1988. An updated paradigm for scale development incorporating unidimensionality and its assessment. Journal of Marketing Research 25: 186-192.

Godinho, F. N., and M. T. Ferreira. 1998. The relative influence of exotic species and environmental factors on an Iberian native fish assemblage. Environmental Biology of Fishes 51:41-51.

Godinho, F. N., M. T. Ferreira, and R. V. Cortes. 1997. Composition and spatial organization of fish assemblages in the lower Guadiana basin, southern Iberia. Ecology of Freshwater Fish 6:134-143.
Gurevitch, J., and D. K. Padilla. 2004. Are invasive species a major cause of extinctions? Trends in Ecology and Evolution 19:470-474.

Havel, J. E., C. E. Lee, and M. J. V. Zanden. 2005. Do reservoirs facilitate invasions into landscapes? BioScience 55: $518-525$.

Hermoso, V., F. Blanco-Garrido, and J. Prenda. 2008. Spatial distribution of exotic fish species in the Guadiana River basin with two new records. Limnetica 27:189-194.

Hermoso, V., M. Clavero, F. Blanco-Garrido, and F. Prenda. 2009a. Assessing freshwater fish sensitivity to different sources of perturbation in a Mediterranean basin. Ecology of Freshwater Fish 18:269-281.

Hermoso, V., M. Clavero, F. Blanco-Garrido, and J. Prenda. 2010. Assessing the ecological status in species-poor systems: a fish-based index for Mediterranean rivers (Guadiana River, SW Spain). Ecological Indicators 10:1152-1161.

Hermoso, V., S. Linke, and J. Prenda. 2009b. Identifying priority sites for the conservation of freshwater fish biodiversity in a Mediterranean basin with a high degree of threatened endemics. Hydrobiologia 623:127-140.

Hughes, R. M., D. P. Larsen, and J. M. Omernik. 1986. Regional reference sites: a method for assessing stream potential. Environmental Management 10:629-635.

IUCN. 2008. IUCN red list of threatened species. 〈www. iucnredlist.org $\rangle$

Jackson, R. A., P. R. Peres-Neto, and J. D. Olden. 2001. What controls who is where in freshwater fish communities: the roles of biotic, abiotic, and spatial factors. Canadian Journal of Fisheries and Aquatic Science 58:157-170.

Johnson, P. T. J., J. D. Olden, and M. J. Vander Zanden. 2008. Dam invaders: impoundments facilitate biological invasions into freshwaters. Frontiers in Ecology and the Environment $6: 357-363$.

Kolar, C. S., and D. M. Lodge. 2000. Freshwater nonindigenous species: interactions with other global changes. Pages $3-$ 30 in H. A. Mooney and R. J. Hobbs, editors. Invasion species in a changing world. Island Press, Washington, D.C., USA.

Leprieur, F., O. Beauchard, S. Blanchet, T. Oberdorff, and S. Brosse. 2008. Fish invasions in the world's river systems: when natural processes are blurred by human activities. PLoS Biology 2:e28.

Light, T., and M. P. Marchetti. 2006. Distinguishing between invasions and habitat changes as drivers of biodiversity loss among California's freshwater fishes. Conservation Biology 21:434-446.

Linke, S., R. H. Norris, D. P. Faith, and D. Stockwell. 2005. ANNA: a new prediction method for bioassessment programs. Freshwater Biology 50:147-158.

Lozon, J. D., and H. J. MacIsaac. 1997. Biological invasions: are they dependent on disturbance? Environmental Reviews 5:131-144.

MacDougall, A. S., and R. Turkington. 2005. Are invasive species the drivers or passengers of change in degraded ecosystems? Ecology 86:42-55.

Magalhães, M. F., D. C. Batalha, and M. J. Collares-Pereira. 2002. Gradients in stream fish assemblages across a Mediterranean landscape: contributions of environmental factors and spatial structure. Freshwater Biology 47:10151031.

Malmqvist, B., and S. Rundle. 2002. Threats to the running water ecosystems of the world. Environmental Conservation 29:134-153.

Marchetti, M. P., T. Light, P. B. Moyle, and J. H. Viers. 2004. Fish invasions in California watersheds: testing hypotheses using landscape patterns. Ecological Applications 14:15071525.

Marchetti, M. P., and P. B. Moyle. 2000. Spatial and temporal ecology of native and introduced fish larvae in lower Putah 
Creek, California. Environmental Biology of Fishes 58:7587.

Marchetti, M. P., and P. B. Moyle. 2001. Effects of flow regime and habitat structure on fish assemblages in a regulated California stream. Ecological Applications 11:530-539.

Matthews, W. A. 1998. Patterns in freshwater fish ecology. Chapman and Hall, New York, New York, USA.

McGarvey, D. J., and R. M. Hughes. 2008. Longitudinal zonation of Pacific Northwest (U.S.A.) fish assemblages and the species-discharge relationship. Copeia 2008:311-321.

Mitchell, R. J. 1993. Path analysis: pollination. Pages 211-231 in S. M. Scheiner and J. G. Gurevitch, editors. Design and analysis of ecological experiments. Chapman and Hall, New York, New York, USA.

Moreno-Valcárcel, R. 2006. Gestión de species exóticas: bases biológicas para el control de Gambusia holbrooki en Lugares de Importancia Comunitaria (LICs) en la región de Murcia. Technical report. University of Murcia, Murcia, Spain.

Moyle, P. B. 2002. Inland fishes of California, revised and expanded. University of California Press, Berkeley, California, USA

Moyle, P. B., and T. Light. 1996. Biological invasions of freshwater: empirical rules and assembly theory. Biological Conservation 78:149-161

Munné, A., N. Prat, C. Solá, N. Bonada, and M. Rieradevall. 2003. A simple field method for assessing the ecological quality of riparian habitat in rivers and streams: QBR index. Aquatic Conservation: Marine and Freshwater Ecosystems 13:147-163.

Myers, J. H., D. A. Simberloff, A. M. Kuris, and J. Carey. 2000. Eradication revisited: dealing with exotic species. Trends in Ecology and Evolution 15:316-320.

Ninyerola, M., X. Pons, and J. M. Roure. 2005. Atlas climático digital de la Península Ibérica. Metodología y aplicaciones en bioclimatología y geobotánica. Universidad Autónoma de Barcelona, Bellaterra, Spain.

Oakes, R. M., K. B. Gido, J. A. Falke, J. D. Olden, and B. L. Brock. 2005. Modelling of stream fishes in the Great Plains, USA. Ecology of Freshwater Fish 14:361-384.

Olson, D. M., E. Dinerstein, G. V. N. Powell, and E. D. Wikramanayake. 2002. Conservation biology for the biodiversity in crisis. Conservation Biology 16:1-3.

Pimm, S. L., G. J. Rusell, J. L. Gittleman, and T. M. Brooks. 1995. The future of biodiversity. Science 269:347-350.

Pont, D., B. Hugueny, and C. Rogers. 2007. Development of a fish-based index for the assessment of river health in Europe: the European fish index. Fisheries Management and Ecology $14: 427-439$

Reyjol, Y., et al. 2007. Patterns in species richness and endemism of European freshwater fish. Global Ecology and Biogeography 16:65-75.
Reynoldson, T. B., R. H. Norris, V. H. Resh, K. E. Day, and D. M. Rosenberg. 1997. The reference condition: a comparison of multimetric and multivariate approaches to assess water-quality impairment using benthic macroinvertebrates. Journal of the North American Benthological Society 16: 833-852.

Ribeiro, F., B. Elvira, M. J. Collares-Pereira, and P. B. Moyle. 2008. Life-history traits of non-native fishes in Iberian watersheds across several invasion stages: a first approach. Biological Invasions 10:89-102.

Ricciardi, A. 2004. Assessing species invasions as a cause of extinction. Trends in Ecology and Evolution 19:619.

Rischbieter, C. 2000. Structures to prevent the spread of nuisance fish from Lake Davis, California. North American Journal of Fisheries Management 20:784-790.

Sály, P., T. Erós, P. Takács, A. Specziár, I. Kiss, and P. Bíró. 2009. Assemblage level monitoring of stream fishes: the relative efficiency of single-pass vs. double-pass electrofishing. Fisheries Research 99:226-233.

Saunders, D. L., J. J. Meeuwig, and A. C. J. Vincent. 2002. Freshwater protected areas: strategies for conservation. Conservation Biology 16:30-41.

Schlosser, I. J. 1987. A conceptual framework for fish communities in small warmwater streams. Pages 17-24 in W. J. Matthews and D. C. Heins, editors. Community and evolutionary ecology of North American stream fishes. University of Oklahoma Press, Norman, Oklahoma, USA.

Shea, K., and P. Chesson. 2002. Community ecology theory as a framework for biological invasions. Trends in Ecology and Evolution 17:170-176.

Shipley, B. 2000. Cause and correlation in biology: a user's guide to path analysis, structural equations, and causal inference. Cambridge University Press, Cambridge, UK.

Smith, K. G., and W. R. T. Darwall. 2006. The status and distribution of freshwater fish endemic to the Mediterranean Basin. IUCN, Gland, Switzerland and Cambridge, UK.

Trexler, J. C., W. F. Loftus, F. Jordan, J. J. Lorenz, J. C. Chick, and R. M. Kobza. 2000. Empirical assessment of fish introductions in a subtropical wetland: an evaluation of contrasting views. Biological Invasions 3:265-377.

Vila-Gispert, A., C. Alcaraz, and E. García-Berthou. 2005. Life-history traits of invasive fish in small Mediterranean streams. Biological Invasions 7:107-116.

Wittenberg, R., and M. J. W. Cock. 2001. Invasive alien species: a toolkit of best prevention and management practices. CAB International, Wallingford, Oxon, UK.

Wootton, J. T. 1994. Predicting direct and indirect effects: an integrated approach using experiments and path analysis. Ecology 75:151-165.

Zavaleta, E. S., R. J. Hobbs, and H. A. Mooney. 2001. Viewing invasive species removal in a whole-ecosystem context. Trends in Ecology and Evolution 16:454-459.

\section{APPENDIX}

Complete list of environmental variables used in the modeling step (Ecological Archives A021-010-A1). 